of periosteal activity is repeated at intervals of about one week.

Department of Pathology,

Royal College of Surgeons of England, London, W.C.2. Jan. 24.

'Barclay, A. E., Brit. J. Radiol., 20. 394 (1947).

\section{Difference in Structure between the same Giant Chromosomes from the same Larvæ of Drosophila repleta}

IN a previous paper we have shown that the pattern of the same giant chromosomes can differ from cell to cell even in the same tissue of a Chironomus larva 1. Furthermore, the same giant chromosome structure in different tissues shows normally a different pattern ${ }^{2-6}$. The latter differences are clearly greater than those of the chromosome in the same tissue. On the other hand, an examination of giant chromosomes in the mid-gut and in the salivary gland of Sciara larva led Berger to the conclusion that the pattern of the mid-gut chromosomes is identical with that of the salivary gland chromosomes? ${ }^{7}$ I have investigated both these points with a different object, namely, Drosophila repleta. Giant chromosomes closely resembling those of the salivary gland can be found in various somatic tissues in the larvæ of D. repleta. They are, however, smaller and have fewer cross-bands than the salivary gland chromosomes. The same phenomenon was observed in $D$. virilis by Makino ${ }^{8}$. Besides the salivary gland chromosomes, those in the cells at the base of the large tracheal tubes give the most satisfactory results.

I have compared the same free end of one of the long chromosomes. The figure shows that the same region does not always have the same number of crossbands in all nuclei, either of the salivary gland or of the tracheal cell. Only some cross-bands are regularly present in these chromosomes in each tissue; but more can be found if the giant chromosomes are especially enlarged. If we compare the salivary gland chromosomes with those of the tracheal cells, we see that the former usually have more cross-bands than the same chromosomes in the tracheal cells (Figs. $a-d$ and $e-g$ ). On the other hand, a small salivary gland chromosome often has the same pattern as a large tracheal chromosome (Figs. $c$ and $e$ ).

Hence both salivary gland and tracheal chromosomes develop with the same trend; but the process that leads to the formation of cross-bands goes on more quickly and more strongly in the salivary

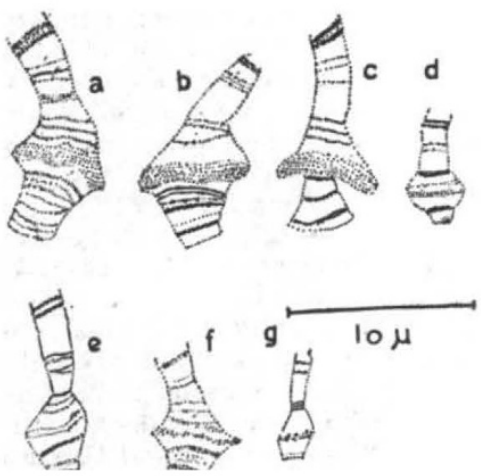

Salivary gland chromosomes $(a-d)$, and tracheal chromosomes at the base of the large tracheal tubes $(e-g)$ gland chromosomes than in the others. This causes the different pattern in the same chromosome in the two tissues.

Department of Zoology,

AtIF SENGÜN

University of Istanbul. Jan. 8.

'Sengün, A., Rev. Fac. Sci, Univ. Istanbui, B, 13 (1947).

${ }^{2}$ Kosswig, C., and Sengïn, A., Rev. Fas. Sci. Univ. Istanbul, B, 13 (1947).

${ }^{3}$ Kosswig, C., and Sengün, A., C.R. Ann. et Arch. Soc. Turque Sci., phys. et Nat., 13 (1947).

4 Kosswig, C., and Sengün, A., J. Hered., 38 (1947).

${ }^{5}$ Sengün, A., Comm. Fac. Sci. Univ. Ankara, 1 (1948).

- Sengün, A., and Kosswig, C., Chromosoma, 3 (1948).

7 Berger, C. A., J. Hered., 31 (1940).

${ }^{8}$ Makino. S., Cytologia. 9 (1938).

\section{A Labyrinthodont from the Trias of Bear Island, Spitsbergen}

DURING the course of an ecological survey of Bear Island in the summer of 1948 , a nearly complete labyrinthodont skeleton was found lying horizontally in the fissile shales of the Mount Misery plateau. These shales are believed to belong to the Upper Triassic, and the overlying "Myophoria Sandstone" has a rich marine fauna of Carnian age ${ }^{1}$. The site was about $430 \mathrm{~m}$. above sea-level on the southern slopes of Urd (the highest point on the island and the most southerly of the three peaks of Mount Misery), about $100 \mathrm{~m}$. below the peak and very close to the edge of the steep slopes falling to the sea on the southern side.

The whole fossil, which appears to be that of a large brachyopid, measured approximately $2 \cdot 6 \mathrm{~m}$. from the tip of the nose to the last preserved caudal centrum. The skull measured $70 \mathrm{~cm}$. across the horns, and $21 \mathrm{~cm}$. from the tip of the nose to the back of the dorsal surface of the skull in the mid-line. Twentyfour ribs were exposed on the left side and nineteen on the right. A nearly complete rib from the thoracic region measured $30 \mathrm{~cm}$. in length. Some parts of the limb girdles were seen, and the remains of about thirty vertebræ. Approximately $45 \mathrm{~cm}$. of the caudal region was preserved.

All the bones were broken into a large number of fragments, and with the available equipment the fossil could not be collected. In view of the almost certain loss which would result from the oncoming winter weather, sample bones were collected and certain parts were embedded in paraffin-wax (the only available embedding material). Photographs taken by Mr. N. Creasey gave considerable informa. tion concerning the proportions of the skull and body.

Consideration of the available data indicates that the animal was a plagiosaur with skull proportions much like those of Gerrothora $x^{2}$ but of relatively enormous size.

It is hoped that a Norwegian expedition will be able to visit Bear Island in an endeavour to find more and possibly better material.

I. wish to thank Mr. F. R. Parrington for his interest in this find, and to acknowledge the help given by $\mathrm{Mr}$. E. Duffey and Mir. D. E. Sergeant in the collection of the material.

\section{J. Lowy}

Zoological Laboratory,

Cambridge. Jan. 15.

Horn, H., and Orvin, A. K., Skrifter om Svalvard og Ishavet, No. 15
(Oslo, 1928). ${ }^{2}$ Nilsson, T., Lunds Univ., Årsskr., N.F., 42, No. 10 (1946). 